\title{
medicina intensiva
}

www.elsevier.es/medintensiva

IMÁGEN EN MEDICINA INTENSIVA

\section{Edema pulmonar unilateral letal tras evacuación de neumotórax espontáneo}

\section{Fatal unilateral pulmonary edema after spontaneous pneumothorax evacuation}

\section{F.J. Romero-Bermejo*, M. Ruiz-Miralles y J. Gómez Ramos}

Unidad de Medicina Intensiva, Hospital Universitario Puerto Real, Cádiz, España

Recibido el 15 de abril de 2010; aceptado el 16 de abril de 2010
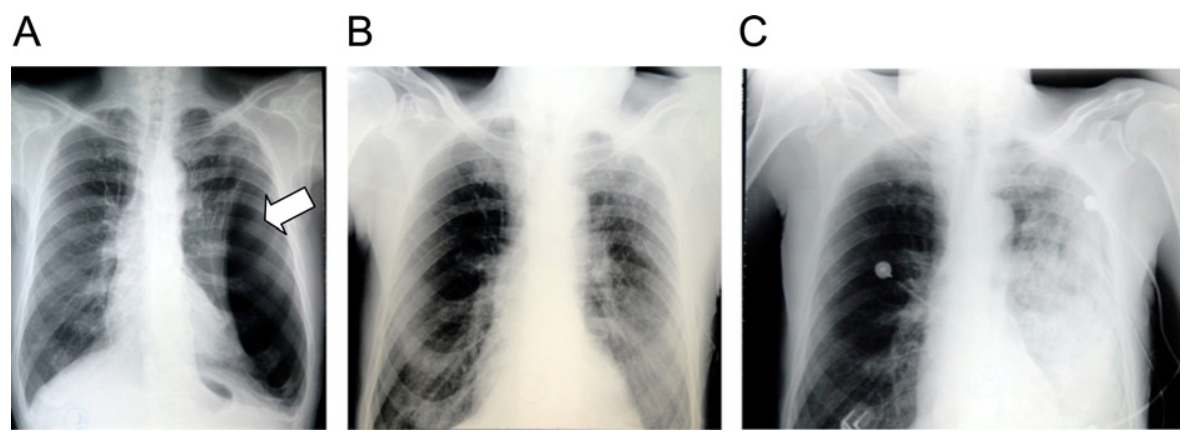

Figura 1 A) Neumotórax izquierdo. B) Se insertó un tubo de drenaje torácico. C) Nueva RX de tórax mostró imágenes compatibles con edema pulmonar unilateral.

Paciente de 68 años de edad, fumador inveterado con criterios clínicos de EPOC, que acudió al servicio de urgencias de nuestro hospital por disnea progresiva hasta hacerse a mínimos esfuerzos de 2 semanas de evolución. No refería traumatismo torácico. Radiológicamente, se diagnosticó un neumotórax izquierdo (fig. 1A). Se insertó un tubo de drenaje torácico, se reexpandió completamente el pulmón y mejoró así la clínica del paciente (fig. 1B). Tres horas más tarde tuvo un deterioro clínico consistente en dificultad respiratoria grave. Se auscultaban estertores húmedos de gruesa burbuja en el hemitórax izquierdo. Una nueva RX de tórax mostró imágenes compatibles con edema pulmonar unilateral (fig. 1C). Fue preciso conectarlo a ventilación mecánica y que recibiera tratamiento vasoactivo. El paciente entró en estado de choque refractario y falleció pocas horas después.

\footnotetext{
* Autor para correspondencia.

Correo electrónico: romerobermejo@gmail.com (F.J. Romero-Bermejo).
} 